\title{
DIREITO, ANISTA E PERDÃO: A PARTIR DA PERSPECTIVA DE PAUL RICOEUR
}

Mariana P. Fischer Pacheco ${ }^{1}$ Tassiana Bezerra dos Santos ${ }^{2}$

LAW, AMNESTY AND PARDON: FROM THE

PERSPECTIVE OF PAUL RICOEUR

RESUMO: Nos últimos dez anos, no Brasil, o debate sobre direito, anistia e memória ganhou elevada relevância. O discurso jurídico dominante é ser, contudo, pouco sensível a reflexões realizadas por diferentes linhagens da filosofia e da crítica social sobre os riscos de associar anistia e esquecimento. Dentre as diversas tradições que se ocupam com a questão, a hermenêutica de Paul Ricoeur, em especial, investiga tensões entre uma anistia juridicamente determinada e o perdão, que exige memória e extrapola o campo do direito. Ora, se o perdão ultrapassa o direito, seria, então, uma tarefa inócua, para juristas, discuti-lo? Poderia uma reflexão sobre o tema ter efeitos relevantes na ordem jurídica? Para responder a essas perguntas, olharemos para as diferenças entre os casos brasileiro e sul-africano e discutiremos a possibilidades de realizar conexões produtivas direito e um ambiente de zelo pela memória e pelo pedido de perdão.

Palavras-chave: Direito. Anistia. Perdão. Memória. Hermenêutica.
ABSTRACT: In the last ten years, in Brazil, the debate about law, amnesty and memory has gained a major relevance. The hegemonic legal discourse, however, have neglected the ideas of various traditions of philosophy and social criticism on the risks of associating amnesty and forgetfulness. Paul Ricoeur investigated this problem, in particular, he tried to understand the tensions between a legally determined amnesty and the question of pardon, one that is connected to memory and that exceeds the law. If pardon surpasses law, would it be pointless for jurists to discuss it? Could an investigation on the matter have relevant effects on the legal order? We will look at the differences between Brazilian and South African amnesty (the latter was examined by Ricoeur) in order to discuss productive possibilities of connection between law and a context of care for memory and pardon.

\section{Keywords: Law. Amnesty. Pardon. Memory.} Hermeneutics.

\footnotetext{
${ }^{1}$ Professora Adjunta em regime de Dedicação Exclusiva do Departamento de Direito Público Geral e Processual da Universidade Federal de Pernambuco. Mestre em Doutora em Direito pela UFPE, Pós-Doutora em Filosofia pela USP.

${ }^{2}$ Mestre em Direito pelo Programa de Pós-Graduação em Direito da Universidade Federal de Pernambuco.
} 


\section{INTRODUÇÃO: ANISTIA OU PERDÃO?}

Nos últimos dez anos, no Brasil, a discussão sobre direito, anistia e esquecimento ganhou elevada relevância, principalmente em razão de debates sobre interpretação da Lei de Anistia e acerca da instauração e funcionamento de uma Comissão da Verdade. Em 2010, o Supremo Tribunal Federal (STF) decidiu que a anistia contra ofensas realizadas no período da ditadura militar deveria ser estendida a todos, inclusive aos agentes do Estado que violaram direitos humanos. Um breve exame do contexto e dos argumentos dos ministros do STF (especialmente a tese de que anistia deve ser interpretada como sinônimo de perdão) nos permitirá observar certa insensibilidade, peculiar aos juristas, a reflexões realizadas por diferentes linhagens da filosofia e da crítica social acerca dos perigos do esquecimento. Dentre as diversas tradições que se dedicaram a pensar a questão, a hermenêutica de Paul Ricoeur interessa-nos especialmente, já que sua "pedagogia do perdão" (DUFFY, 2009) ocupa-se justamente com tensões entre uma anistia juridicamente determinada e o perdão que extrapola o campo do direito.

Toda narrativa é seletiva no sentido de que põe luz em certos acontecimentos que parecem ser mais significativos e deixa outros na obscuridade. Certo modo de esquecer constitui, portanto, a própria possibilidade de narrar. Nesse sentido, como veremos, Ricoeur escreve sobre diferentes maneiras de contar histórias sobre o passado, as quais estão conectadas a diversos tipos de esquecimento. Refere-se, assim, a um esquecimento de fuga ou em um esquecimento comandado, o qual caracterizou a anistia no Brasil e na América Latina, e, de outro lado, um esquecimento ativo ligado ao perdão, que começa com o trabalho da memória e termina com a escolha de esquecer. São esses matizes do esquecimento que o discurso jurídico dominante brasileiro parece negligenciar.

Veremos que um trabalho de lembrança e de luto faz parte do percurso do perdão. O perdão, contudo, demanda mais do que trabalho, pois pertence à lógica do dom ou da superabundância, nesse sentido, sempre irá extravasar o direito. Seria, então, uma tarefa inócua refletir sobre direito e perdão? Poderia uma discussão sobre o perdão e sobre um esquecimento ativo ter consequências importantes para o direito? Ricoeur toca nessas questões ao examinar o caso da anistia na África do Sul. Parece-nos, portanto, que olhar 
para as diferenças entre o caso sul africano e brasileiro pode abrir um caminho produtivo de investigação.

Esse artigo está organizado da seguinte maneira. Em primeiro lugar, abordaremos o debate atual entre os juristas brasileiros acerca da Lei de Anistia e mostraremos que, nesse ambiente, o argumento dominante é aquele que faz equivaler anistia e perdão. Em seguida, problematizaremos tal ponto de vista e buscaremos aprofundar a investigação a partir da leitura feita por Ricoeur de três conceitos da psicanálise freudiana: compulsão à repetição, trabalho de elaboração (Durcharbeiten) e luto. Buscaremos, então, compreender a relação entre perdão e dom. Por fim, examinaremos o caso da "Comissão da Verdade e Reconciliação" da África do Sul que, em vez de uma anistia ampla, geral e irrestrita como a brasileira, optou por realizar uma anistia individualizada (isto é, que não estava associada a uma imunidade coletiva, mas a crimes específicos e bem identificados) e condicionada à confissão do ofensor.

\section{CASO BRASILEIRO: UMA ANISTIA AMPLA, GERAL E IRRESTRITA}

A Lei no 6.683 promulgada em 28 de agosto de 1979, a Lei de Anistia foi criada com o objetivo de anistiar tanto agentes do Estado como aqueles que resistiram ao regime militar. Falava-se à época em um pacto da sociedade e que uma nação, para sobreviver, deveria se mostrar capaz de esquecer algumas coisas (REIS, 2000). Dispõe a referida Lei:

Art. 1 - É concedida anistia a todos quantos, no período compreendido entre 02 de setembro de 1961 e 15 de agosto de 1979, cometeram crimes políticos ou conexo com estes, crimes eleitorais, aos que tiveram seus direitos políticos suspensos e aos servidores da Administração Direta e Indireta, de fundações vinculadas ao poder público, aos Servidores dos Poderes Legislativo e Judiciário, aos Militares e aos dirigentes e representantes sindicais, punidos com fundamento em Atos Institucionais e Complementares (vetado).

$\S 1$ o - Consideram-se conexos, para efeito deste artigo, os crimes de qualquer natureza relacionados com crimes políticos ou praticados por motivação política (BRASIL, 1979).

Em 2008, o Conselho Federal da Ordem dos Advogados do Brasil (OAB) ajuizou uma ADPF (153) - Arguição de Descumprimento de Preceito Fundamental - no Supremo Tribunal Federal argumentando que os crimes comuns cometidos pelos agentes do Estado, como tortura, não poderiam ser considerados crimes conexos. Tal entendimento estaria 
em desacordo com a Constituição e a com a própria noção de democracia e Estado de Direito.

uma interpretação conforme a Constituição, de modo a declarar, à luz de seus preceitos fundamentais, que a anistia concedida pela citada lei aos crimes políticos ou conexos não se estende aos crimes comuns praticados pelos agentes da repressão contra opositores políticos, durante o regime militar (BRASIL, 2010, p. 29).

$A O A B$ defendeu que incluir crimes comuns praticados pelos agentes estatais no elenco de crimes conexos significaria supor que o que ocorreu na ditadura foi uma luta entre iguais, em vez de reconhecer que foi instaurado, naquele momento um regime de exceção, no qual o próprio Estado conduziu reiteradas e flagrantes ofensas aos direitos humanos.

Tal como a $O A B$, na época da ditadura e também no tempo presente, muitos juristas se opuseram a tal modelo de anistia (REIS, 2000), atualmente, contudo, a interpretação dominante é aquela que defende uma anistia ampla, geral e irrestrita. Manuais de teoria do direito costumam justificar esse posicionamento por meio do argumento de que a reconciliação apenas seria possível pelo esquecimento e pelo abandono do ímpeto de punição que, segundo alguns, estaria atrelado à vingança. Dimoulis (2010), por exemplo, sustenta que "declarar a nulidade parcial da Lei da Anistia (sob o manto de uma "nova interpretação") significaria satisfazer instintos de vingança, ainda que disfarçados em um discurso de boas intenções, repleto de referências a "direitos humanos" e à "comunidade internacional".

Em resposta à ADPF proposta pela OAB, venceu, por sete votos a dois, no STF, a interpretação segundo a qual, para conduzir a reconciliação pretendida, a Lei de Anistia deve ser estendida aos agentes da repressão. Os votos que seguiram a decisão do ministro relator, Eros Grau, utilizam como fundamento a necessidade dessa Lei para que a nação pudesse deixar para trás aquele período ditatorial e, pacificamente, tornar-se uma democracia. Neste sentido, Ellen Gracie argumenta:

não se faz transição, ao menos não se faz transição pacífica, entre um regime autoritário e uma democracia plena, sem concessões recíprocas. Por incômodo que seja reconhecê-lo hoje, quando vivemos outro e mais virtuoso momento histórico, a anistia, inclusive daqueles que cometeram crimes nos porões da ditadura, foi o preço que a sociedade brasileira pagou para acelerar o processo 
pacífico de redemocratização, com eleições livres e a retomada do poder pelos representantes da sociedade civil (BRASIL, 2010, p. 153).

Na continuação de seu voto, a ministra trata anistia e perdão como sinônimos:

já o pedido alternativo de interpretação conforme que retirasse do âmbito de abrangência da lei os atos praticados pelos agentes da repressão tampouco pode ser atendido. Anistia é, em sua acepção grega, esquecimento, oblívio, desconsideração intencional ou perdão de ofensas passadas. É superação do passado com vistas à reconciliação de uma sociedade. E é, por isso mesmo, necessariamente mútua. (BRASIL, 2010, p. 152. Grifos nossos).

O Ministro Marco Aurélio também compreende as duas palavras como equivalentes:

a anistia é o apagamento do passado em termos de glosa e responsabilidade [...]. [...] anistia é virada de página definitiva, é perdão em sentido maior, desapego a paixões que nem sempre contribuem para o almejado avanço cultural [...]. Anistia é ato abrangente de amor, sempre calcado na buscado convívio pacífico dos cidadãos (BRASIL, 2010, p. 155, grifos nossos).

Tal entendimento, que equipara anistia e perdão, não é uma peculiaridade do pensamento jurídico brasileiro ou mesmo latino-americano (lembremos que as anistias na América Latina, tal como no Brasil, foram também amplas, gerais e irrestritas). De fato, foi reproduzido com frequência na história das ideias jurídicas. Ricoeur (2007) debruça-se sobre o caso francês, em que o Edito de Nantes promulgado por Henrique IV já dispunha: "que a memória de todas as coisas de ambos os lados desde o início do mês de março de 1585 até nosso advento à coroa, e durante todos os distúrbios precedentes, e quando deles, permanecerá apagada e adormecida como coisa não ocorrida" (p. 461). Posteriormente, na república francesa, a anistia deixa de se fundamentar no poder régio, sua fonte passa a ser o povo, o qual pode determinar um esquecimento jurídico que põe um fim aos processos em andamento e suspende ações judiciais.

Pretende-se, assim, realizar um esquecimento institucional supostamente capaz de interromper a violência de situações como guerras civis ou mudanças bruscas de regime político e propiciar a reconciliação entre cidadãos inimigos. Muito embora a hegemonia de tal ponto de vista no direito brasileiro não surpreenda, importa notar que reflete uma particular insensibilidade dos juristas a reflexões formuladas por importantes linhagens da 
filosofia e da teoria social. Lembremos como pensadores das tradições hermenêutica (da qual Ricoeur faz parte), frankfurtiana e pós-estruturalista não se cansam de falar sobre os riscos do esquecimento e acerca da relação entre memória e reconciliação. Ricoeur (2007, p. 460) escreve que, de fato, a anistia foi muitas vezes compreendida como amnésia, mas é justamente por isso que se afasta do perdão:

\begin{abstract}
a anistia, enquanto esquecimento institucional, toca nas próprias raízes do político e, através deste, na relação mais profunda e mais dissimulada com um passado declarado proibido. A proximidade mais que fonética, e até mesmo semântica, entre anistia e amnésia aponta para a existência de um pacto secreto com a denegação da memória que, como veremos mais adiante, na verdade, a afasta do perdão após ter proposto sua simulação.
\end{abstract}

Uma investigação mais aprofundada acerca do tema nos permite compreender que uma anistia que se confunde com esquecimento imposto, em vez de garantir a superação do autoritarismo do passado, produz um modo particular de repeti-lo. Ao estabelecer como e o que deve ser lembrado, o Estado determina a construção de uma narrativa sobre fatos pretéritos e ao mesmo tempo impede a constituição de outros modos de contar a história. Impõe, assim, a fixação em uma única identidade nacional, afinal:

\begin{abstract}
o que é feito, então, do pretenso dever de esquecimento? Além do fato de uma projeção no futuro no modo imperativo ser tão imprópria para o esquecimento quanto para a memória, tal mandamento equivaleria a uma amnésia comandada. Se esta conseguisse ter êxito - e infelizmente nada se constitui em obstáculo à ultrapassagem da tênue linha de demarcação entre anistia e amnésia -, a memória privada e coletiva seria privada da salutar crise de identidade que possibilita uma reapropriação lúcida do passado e de sua carga traumática. Aquém dessa provação, a instituição da anistia só pode responder a um desígnio de terapia social emergencial, sob o signo da utilidade e não da verdade (RICOEUR, 2007, p. 462).
\end{abstract}

Muito diferente da anistia é o perdão, porque "se me detenho um pouco na questão da anistia, é porque, apesar das aparências, ela não prepara de modo algum para a justa compreensão da ideia de perdão. Em muitos aspectos, ela constitui a sua antítese" (RICOEUR, 2008, P.194). É justamente o esquecimento comandado que configurou tanto a anistia brasileira como de diversos países da América Latina que a coloca a anistia em uma posição antitética ou como um obstáculo ao perdão. Devemos, portanto, tentar compreender melhor como ocorre e quais as consequências esse tipo de esquecimento. Existiria outro modo de esquecer? 


\section{QUE TIPO DE ESQUECIMENTO?}

A discussão acerca do perdão envolve um questionamento sobre a possibilidade de reconciliação com fatos ocorridos no passado e ao mesmo tempo com o problema da culpabilidade. Para romper a ligação entre vítima e algoz seria preciso deixar algo para trás. Importa, contudo, perguntar: que tipo de esquecimento pode nos ajudar a deixar realmente o passado para trás e que tipo de esquecimento nos impele a repeti-lo?

Ricoeur toma Freud como referência para pensar a questão. Realiza ainda um complemento à teoria psicanalítica ao avançar no exame de consequências dessas questões para a crítica social. Ressaltemos que uma leitura atenta da teoria freudiana nos faz ver tal ímpeto de pensar a psicanalise para além de sua dimensão estritamente subjetiva já estava presente em Freud, principalmente em seus "textos sociológicos" 3 . O que Ricoeur faz, portanto, é levar adiante tal impulso aproximando-o de reflexões presentes na tradição hermenêutica (RICOUER, 1977, 2010, 2013, 2014).

O filósofo insiste que a memória extrapola o individualismo de uma perspectiva egológica e, do mesmo modo, ultrapassa uma sociologismo que defende que consciência individual se dissolveria na coletividade (RICOEUR, 2007, 2014). A memória que aparentemente seria somente do sujeito, é, de fato, constituída de maneira compartilhada: é do sujeito e ao mesmo tempo de outro. Memória individual e coletiva não são idênticas, mas se realizam de maneira cruzada, já que viver é sempre viver junto com outro. Assim, "o que vale efetivamente para a memória pessoal vale também para a memória partilhada e, acrescentaria, igualmente para a História escrita pelos historiadores" (RICOEUR, 1996, p. 27).

Ricoeur interessa-se, sobretudo, por três conceitos freudianos: compulsão à repetição, elaboração do passado (Durcharbeiten) e luto. O fenômeno da compulsão à repetição é descrito por Freud da seguinte maneira: "casos em que o indivíduo parece vivenciar passivamente algo que está fora de sua influência, quando ele apenas vivencia, de fato, a repetição do mesmo" (FREUD, 2010c, p. 134). Na clínica psicanalítica, a

\footnotetext{
3 É assim que se costuma referir a textos como "Totem e tabu", "Moises e o monoteísmo", "O mal-estar na civilização" em que a preocupação freudiana com a relação entre sujeito e cultura fica mais evidente.
} 
compulsão à repetição se manifesta especialmente na transferência, isto é, em situações em que o analisante reproduz comportamentos e afetos ligados ao material reprimido na relação com o psicanalista. Freud mostra que em um primeiro momento do tratamento, há, usualmente, a lembrança e verbalização de eventos marcantes para o analisante, mas, posteriormente, essa rememoração vai se tornando insuportável. Forças de resistência começam a atuar de maneira mais intensa, impedindo a chegada de certas lembranças à consciência. O que não é rememorado é expelido de outra forma: não através de palavra, mas de atos. Repete-se na vida do sujeito sem que esse perceba. Além da transferência na clínica, Freud (2010c) fornece diversos exemplos que ilustram como a compulsão à repetição se manifesta, como o caso de uma mulher que se casou por três vezes seguidas com homens que rapidamente adoeciam e exigiam seus cuidados antes de morrer.

Freud busca ainda esclarecer como tal ímpeto de repetição pode ser ultrapassado. O trabalho de elaboração (a palavra alemã é Durcharbeiten, também traduzida para o português como perlaboração) ou trabalho de lembrança tem justamente essa função (FREUD, 2010a). O método de tratamento psicanalítico está baseado na livre associação, daí a regra fundamental da clínica: o psicanalista deve pedir ao analisante que deite no divã (sem que possa ver o psicanalista) e fale tudo o que vier à mente por mais doloroso ou aparentemente sem sentido que possa aparentar. O pressuposto é que cada associação que se apresenta na fala tem de ser levada em conta, pois representa a conciliação de forças de resistência e de lembrança que estão em combate. O psicanalista intervêm justamente com o escopo de trabalhar as resistências de maneira que o material recalcado venha a tona. A cura, aqui, significa permitir que o analisante narre sua história de outra maneira e interrompa certas cadeias de repetição.

Ricoeur chama de uso crítico da memória na vida social uma tarefa que considera correspondente ao trabalho de elaboração (Durcharbeiten) freudiano. Para ele, o primeiro modo de lembrar ocorre por meio de narrativas, isto, por meio arte de contar "que encontra nas permutas da vida cotidiana, na História das histórias e nas ficções narrativas, as estruturas apropriadas do linguajar" (RICOEUR, 1996, p. 28). De modo semelhante à teoria psicanalítica, para Ricoeur, a crítica se constitui como uma espécie de zelo por contar histórias que aconteceram no passado, o qual implica em permitir que o outro a 
narre a partir de um ponto de vista que pode me parecer completamente estranho ou destituído de sentido: o olhar retroativo de outro põe luz em aspectos do passado que foram obscurecidos. Tanto na vida do sujeito como no campo social existem resistências a esses outros modos de narrar, são tais resistências que, nos dois casos, necessitam ser superadas.

Pensar a relação entre memória e narrativa significa, para Ricoeur, refletir sobre "a dialética entre passado, presente e futuro" (RICOEUR, 1996, p. 28). É preciso pôr em questão a suposição de que de que unicamente o futuro é indeterminado e de que o passado seria determinado e fechado. Se, de fato, não podemos desfazer aquilo que ocorreu em tempos pretéritos, o sentido de tais ocorrências pode ser transformado. Novas interpretações podem modificar a carga moral do passado, mormente, seu peso de dívida e assim produzir uma reviravolta em projetos para o futuro. É precisamente pela possibilidade de liberação da dívida que o trabalho de lembrança abre a possibilidade do perdão.

Porque o perdão dirige-se não aos acontecimentos cujas marcas devem ser protegidas, mas à dívida cuja carga paralisa a memória e, por extensão, a capacidade de se projetar de forma criadora no porvir. E é toda a dialética do passado e do futuro que é resposta em movimento, o potente projeto no recurso imenso das promessas não realizadas pelo passado (RICOEUR, 1996, p. 28).

O filósofo cuida da conexão entre compulsão à repetição e um tipo específico de esquecimento, que chama de esquecimento de fuga. Ele escreve: "É sobre esta compulsão de repetição que se poderia implantar o esquecimento da fuga, a estratégia da escusa, a tarefa da má-fé, que faz do esquecimento passivo-ativo um empreendimento perverso" (RICOEUR, 1996, p 28). Esse seria um esquecimento em que nada se quer saber sobre um mal cometido e que teria como contrário o esquecimento ativo constituído como complemento do trabalho de lembrança em direção ao perdão.

\section{TRABALHO DE LEMBRANÇA, LUTO E PERDÃO}

Luto é terceiro conceito freudiano utilizado por Ricoeur. Freud investiga em Luto $e$ Melancolia a psicose nomeada por Kraepelin em 1883 de maníaco-depressiva. Tanto o luto como a melancolia se referem à perda de um objeto de forte investimento libidinal, a 
melancolia tem, contudo, uma base narcísica; nela, o trabalho de elaboração da perda não se completa, estagna em um momento específico. Já o luto implica na realização desse trabalho e refere-se a um processo capaz de produzir transformações profundas no sujeito. Maria Rita Kehl (2012, p. 22) escreve: “a falha na constituição do narcisismo primário estabelece uma distinção entre a "neurose narcísica" da melancolia e o sofrimento que caracteriza o trabalho de luto".

A perda do melancólico se dá no início de sua vida e não é percebida pela consciência: o que foi perdido é desde muito cedo esquecido. Ocorre que objeto perdido não é exatamente deixado para trás, como diz Freud (2010b, p. 130), "o objeto não morreu verdadeiramente", ele permanece de um modo peculiar: é introjetado, isto é, ligado ao "eu". O investimento libidinal no objeto é substituído por uma identificação. Tal substituição participa da constituição do sujeito e, para Freud, forma algo como um caráter ou personalidade melancólica. Assim, os afetos ligados a tal perda, como raiva e ressentimento por conta do abandono se voltam contra o próprio sujeito.

Freud (2010b, p. 130) escreve que "o melancólico ainda nos apresenta uma coisa que falta no luto: um extraordinário rebaixamento da autoestima". Recrimina-se e espera castigo. Curiosamente, no entanto, se escutarmos com atenção as autoacusações de um melancólico, perceberemos que elas não se adequam às suas próprias características, parecem se referir a outra pessoa, alguém que foi especialmente significativo em sua vida. O melancólico não se envergonha ao afirmar ser desprezível, ele afirma isso para todos que possam ouvir, pois, sem que perceba, as suas autoacusações são também uma maneira de acusar outra pessoa. Eles

não se envergonham nem se escondem, pois tudo de desabonador que falam de si mesmos se refere, no fundo, a outra pessoa. E estão longe de mostrar, para com aqueles a seu redor, a humildade e a sujeição que convêm a pessoas tão indignas; pelo contrário, são extremamente importunos, agindo sempre como que ofendidos, como se lhes tivesse sido feita uma grande injustiça (FREUD, 2010b, p. 133).

Esse rebaixamento e sentimento de fraqueza é compensado por momentos de afirmações obstinadas de poder ou, como a psicanálise costuma denominar hoje, de mania. Não apenas Ricoeur, outros filósofos contemporâneos como Judith Butler (2004) e, no Brasil, Vladimir Safatle (2015) têm se esforçado para pensar a base melancolia que 
constitui nosso mundo da vida social. Eles se referem constantemente a um laço social que cria um movimento pendular no qual os sujeitos oscilam entre uma busca por maximização da performance e uma profunda sensação de impotência. Certamente, o aumento atual dos diagnósticos de depressão não aconteceu sem motivo.

Se a melancolia se refere a uma perda que não foi elaborada, o luto é justamente o doloroso trabalho que permite a transformação subjetiva ou social após a aceitação da perda. Consiste em um processo de desligamento de um objeto perdido (que é objeto de amor e ao mesmo tempo de ódio) e um movimento de reconciliação que exige lembrança. A superação da dor do enlutado não se dá por meio de um esquecimento de fuga (superação decerto não deve ser confundida com extinção). Luto não leva à aniquilação da dor, constitui sim um tipo de aprendizado acerca de um modo de carregá-la. O sofrimento não vai embora sem deixar marcas, aprendemos a lidar melhor com ele na medida em que admitimos que é parte de nossas vidas. A dor prossegue, é, contudo, modificada, reinscrita na memória.

O trabalho de luto, diz-nos Freud, consiste em desligar-nos por graus do objeto de amor - o qual é também objeto de ódio -, até ao ponto em que poderá ser de novo interiorizado, num movimento de reconciliação semelhante ao que opera em nós o trabalho de lembrança (RICOEUR, 1996, p. 27).

Alcançamos, agora, uma posição que nos permitirá associar mais diretamente tais reflexões sobre luto e trabalho de lembrança ao perdão. A elaboração da perda, que envolve manejo de resistências e a memória, faz parte do início do percurso do perdão. Esse último se opõe, assim, ao esquecimento de fuga da melancolia, o qual, como vimos, produz a permanecia daquilo que se pretende deixar para trás. De fato, como ressalta Ricoeur (2007), não são as lembranças de acontecimentos pretéritos que devem ser desmontadas, o que deve ser destituído, no perdão, é a dívida com relação ao passado.

Devemos perceber ainda que somente há possibilidade do perdão se reconhecermos que há culpabilidade, isto é, que há algo a ser imputado a alguém: "É na região da imputabilidade que a falta, a culpabilidade, deve ser buscada. Essa região é a da articulação entre o ato e o agente, entre o "quê" do atos e o "quem" da potência de agir" (RICOEUR, 2007, p. 468). Ser imputável significa ter a capacidade de narrar e de agir, 
significa liberdade no sentido de que o ser humano pode refazer laços e dar um novo sentido ao seu passado, reinscrevendo um projeto de futuro.

De fato, não pode haver perdão a não ser que se possa acusar alguém, presumi-lo ou declará-lo culpado. E apenas se podem acusar atos imputáveis a um agente que se considera como seu verdadeiro autor. Em outros termos, a imputabilidade é essa capacidade, essa aptidão, em virtude da qual ações podem ser levadas à conta de alguém (RICOEUR, 2007, p. 467).

Em uma primeira olhada, poderíamos ligar a culpabilidade à transgressão de uma regra e a produção de um dano a outrem. Porém, o que realmente interessa a Ricoeur é a confissão de um sujeito que se diz autor de uma ofensa. O sujeito é capaz de tomar a decisão de, por um lado, de pedir perdão e, por outro, receber a imputação. Surge aí altura em que o perdão, como desligamento do agente de sua ação, pode ser concedido. Trata-se de perdoar o culpado sem deixar de condenar a sua ação. O pressuposto é, portanto, o de que o sujeito vale mais do que seus atos, nesse sentido, o único mandamento que está completamente à altura do perdão é aquele sobre amar os inimigos sem recompensa (RICOEUR, 2007).

Vimos que o perdão conjuga um trabalho de lembrança e de luto, gostaríamos, agora, de insistir que está em jogo um elemento adicional: o perdão é mais do que trabalho, pois é preciso pedi-lo. Quem pede perdão a outrem se arrisca no sentido de que seu pedido pode ser recusado, já que "perdão pedido não é o perdão que se tem direito" (RICOEUR, 1996, p. 29). O que se adiciona, então, é um ato de generosidade ligado à economia do dom e da superabundância. Ricoeur revisita, aqui, a noção formulada pelo sociólogo Marcel Mauss, segundo a qual o dom é uma forma arcaica de troca que difere da troca comercial, já que essa última segue a lógica do calculo e do interesse de quem pretende dar para receber algo do mesmo valor. No dom, de outro lado, um ato não equivalente é realizado e só pode ocorrer por ser impulsionado por uma espécie de força situada acima do entendimento. É, nesse sentido, que o pedido de perdão é condicionado e o ato de perdoar é incondicionado (RICOEUR, 2007).

Evocam mais uma vez os obstáculos que barram o acesso à confissão e aqueles, nada menores, que se erigem no limiar da palavra perdão; de fato, pedir perdão também é manter-se disposto a receber uma resposta negativa: não, não posso perdoar. Ora, o modelo da troca considera a obrigação de dar, receber e retribuir como fato consumado. Já vimos que Mauss atribui sua origem à força quase mágica da coisa trocada (RICOEUR, 2007, p. 489). 
Para Ricoeur, o perdão está relacionado à generosidade e se tornará possível justamente no momento em que algo imperdoável é realizado. Há, aqui, outro tipo de esquecimento, que não está ligado à fuga, mas a um pedido, um ato generoso e, finalmente, uma decisão de deixar algo para trás. Esse esquecimento ativo do qual Ricoeur fala pode ocorrer por meio do distanciamento do passado. Refere-se a um afastamento tem o objetivo final de possibilitar uma reconciliação ou uma forma de cura, pois "o perdão acompanha o esquecimento ativo, aquele que ligamos ao trabalho de luto, e é neste sentido que ele cura" (RICOEUR, 1996, p. 28). De um lado a confissão do mal ou de uma falta e, de outro, "o alto hino do perdão" (RICOEUR, 2007, p.465).

O perdão, portanto, extravasa o campo do direito, Ricoeur (2008, p. 196) o conecta à ética:

o perdão não pertence à ordem jurídica; ele nem se quer pertence ao plano do direito. Caberia falar dele como Pascal fala da caridade no famoso trecho das "três ordens": ordem dos corpos, ordem dos espíritos, ordem da caridade. O perdão escapa do direito tanto por sua lógica quanto por sua finalidade.

Mas isso não quer dizer que os juristas devem permanecer indiferentes à questão do perdão, já que "não é vetado perguntar se o perdão não terá algum efeito secundário sobre a própria ordem jurídica, uma vez que, escapando-Ihe, paira sobre ela" (RICOEUR, 2008, p. 197). Ainda que as reflexões sobre o perdão não possam ser convertidas de imediato em discurso jurídico, podemos, a partir delas, obter um norte capaz de nos ajudar a pensar sobre como o direito pode contribuir para que haja um trabalho de lembrança e de luto na vida social. Parece-nos que o exame do caso da "Comissão da Verdade e Reconciliação" (Truth and Reconciliation Commission) da África do Sul pode nos ajudar compreender como essa tarefa pode ser realizada.

\section{CONCLUSÃO: CASO DA “COMISSÃO DA VERDADE E RECONCILIAÇÃO” DA ÁFRICA DO}

\section{SUL E A FORMAÇÃO DE OUTRO MODO DE ANISTIAR}

A Comissão de Verdade e Reconciliação, exigida pelo então presidente da África do Sul Nelson Mandela e presidida pelo bispo Desmond Tutu, deliberou de 1996 até 1998. Tinha o propósito de coletar testemunhos, reabilitar e reparar as vítimas, assim como 
anistiar aqueles que confessassem crimes políticos cometidos entre 1960 e 1994, isto é, durante o regime do apartheid. O "Ato de Promoção da Unidade Nacional e da Reconciliação" de 1995 dispõe sobre os propósitos da Comissão:

realizar uma investigação e estabelecer uma imagem, o mais possível, completa da natureza, causas e alcance de graves violações aos direitos humanos, cometidas no período de 1 de marco de 1960 até a data de interrupção contemplada pela Constituição, dentro ou fora da República, emanadas de conflitos do passado, assim como do destino e situação das vítimas de tais violações; garantir a anistia das pessoas que realizarem uma revelação completa de todos os fatos relevantes ligados a atos associados a objetivos político cometidos no curso de conflitos do passado, durante o referido período; garantir às vítimas a oportunidade de relatar as violações que sofreram; realizar medidas com o objetivo de garantir a reparação, a reabilitação e a restauração da dignidade humana e civil das vítimas de violação de direitos humanos e expor à Nação violações e vítimas (ÁFRICA DO SUL, 1995).

A comissão se dividia em três comitês: o comitê de violação dos direitos humanos, encarregado de investigar as ofensas cometidas, principalmente por meio da escuta de vítimas e ofensores em audições públicas; o comitê de reparação e reabilitação, responsável por fornecer indenizações, suporte material e psicológico às vítimas; comitê de anistia, que tinha a tarefa de orientar os pedidos de anistia, poderia aceitar ou negar os pedidos nos casos de confissão e comprovação das motivações políticas dos incriminados (ÁFRICA DO SUL, 1998).

A anistia foi um dos temas mais debatidos pelos sul-africanos. De um lado movimentos que almejavam punir os criminosos do apartheid e, de outro, os membros do antigo regime, que apoiavam uma anistia ampla, geral e irrestrita, isto é, um processo amnésia social que abdicaria da apuração da verdade. A Comissão sul-africana não seguiu nem uma nem outra orientação, optou por atuar a partir de princípios da justiça restaurativa os quais exigem que "a responsabilização dos ofensores se realize com objetivo de contribuir para o bem estar da vítima" (ÁFRICA DO SUL, 1998, p. 115) e, do mesmo modo, reconhecem a necessidade de dissociar anistia e amnésia:

o fato de que algumas pessoas recebem a liberdade sem se responsabilizar por alguma forma de restituição é o grande problema do processo de anistia. Apenas uma emergência da verdade a qual abre a possibilidade da constituição de uma dinâmica social que inclui uma nova abordagem do sofrimento das vítimas se aproxima do ideal de justiça restaurativa (ÁFRICA DO SUL, 1998, p 115). 
Como escreve Sophie Pons (2000), a grande inovação dos sul-africanos (a qual os distingue dos brasileiros e de outros países da América Latina) reside no fato de que buscaram realizar uma anistia individual e condicional. Individual na medida em que não estava associada a uma imunidade coletiva (de todos aqueles que cometeram os crimes políticos em um período determinado), mas procurava lidar com crimes individualizados, os quais deveriam ser, o mais possível, expostos para toda a sociedade. A anistia era ainda condicionada a uma confissão pública, a qual, entre outros objetivos, pretendia justamente auxiliar na reconstrução dos fatos, especialmente identificar com precisão quais foram as ofensas cometidas. A imunidade não era, portanto, fornecida de maneira automática, dependia de um processo que exigia o contraditório. A principal diferença entre Brasil e África do Sul, neste aspecto institucional, é a de que, aqui, não se assumiu que a ditadura cometeu crimes contra a humanidade: os crimes dos agentes do Estado foram compreendidos como equivalentes aos daquele que resistiram à ditadura. Como vimos, o ponto de vista dominante entre os juristas brasileiros é o de que a anistia deve ser ampla, geral e irrestrita (e não individual e condicional).

O objetivo dos sul-africanos era compreender e não vingar. Não se tratava de construir um discurso que pertencesse somente às vítimas ou somente aos ofensores, o retorno ao passado tinha objetivos dirigidos ao futuro, buscava transformar instituições, subjetividades e, sobretudo, preservar a ligação orgânica que mantém reunida a comunidade humana (TELES, 2007). Tratava-se de zelar pela memória compartilhada e assegurar que as diversas perspectivas fossem expostas e discutidas publicamente de maneira a impactar na vida comum.

Após dois anos de trabalho e a escuta de mais de 20 mil pessoas, a comissão elaborou um relatório de cerca de 3.500 páginas que propôs o indiciamento criminal de autoridades, (como presidente Pieter W Bota) e de instituições políticas ligados ao antigo regime (como o partido nacionalista afrikaner), assim como empresários e empresas internacionais (especialmente a IBM, International Business Machines Corporation, que financiou a informatização do apartheid) (AFRICA DO SUL, 1998).

A reconciliação sul-africana não chegou, contudo, ao seu fim. Ganhou notoriedade a observação do arcebispo católico da África do Sul, Denis Hurley, o qual disse que a 
Comissão da Verdade e da Reconciliação foi maravilhosa no campo da verdade, mas nem tanto no da reconciliação. De fato, a desigualdade racial persiste, as vitimas pouco receberam em compensação ao dano sofrido e as políticas públicas de taxação de grandes empresas que se beneficiaram com o apartheid tiveram efeitos reduzidos (TELES, 2007). Ricoeur (2007) examina o caso e chama a atenção para a difícil tarefa de abrir mão da punição em troca da verdade. Apenas $17 \%$ das confissões foram aceitas (a maior parte delas foi composta por testemunhos incompletos ou informações inverídicas), além disso, a confissão pública foi usada por muitos acusados como tática para escapar de uma ação judicial. De acordo com Ricoeur (2007, p. 491), aqueles que utilizaram estrategicamente as vantagens dos procedimentos de confissão "contribuíram para estabelecer a verdade factual, mas à custa da verdade que liberta. A impunidade de fato de crimes antigos transformou-se, para eles, em impunidade de direito, em recompensa de confissões sem contrição".

Ainda assim, a experiência da Comissão foi fundamental para que os sul-africanos pudessem dar passos importantes em direção à elaboração do passado e ao luto. Ricoeur (2007, p. 489) ressalta que o trabalho realizado com as vítimas e seus familiares implicou em um verdadeiro "exercício público do trabalho da memória e do luto". As audiências da comissão foram guiadas pelo procedimento contraditório e permitiram que as vítimas e seus familiares narrassem o seu sofrimento e confrontassem os ofensores. O processo foi conduzido não por um terceiro supostamente neutro, mas pelos próprios sul-africanos, que puderam contar suas histórias, escutar outras e relatar para um público amplo os acontecimentos que vivenciaram ou testemunharam. A estrutura narrativa das audiências permitiu que a tragédia humana do apartheid fosse discutida, houve um espaço emocional para que o legado de ódio, medo, culpa e vingança pudesse ser abordado (DUFFY, 2009).

O jornalista e poeta Antjie Krog acompanhou a Comissão, mostrou seu potencial e também seus limites. Ele ressaltou a importância de mostrar o passado da África do Sul por meio de recordações ligadas a experiências pessoais das testemunhas, desse modo, foi possível trazer a "verdadeira carne frases retóricas como crimes contra a humanidade" (KROG, 1998, p. vii). Escreve: apartheid para a democracia. Há uma necessidade de compreensão, mas não de 
vingança, uma necessidade de reparação mas não retaliação, uma necessidade de "ubuntu" (filosofia africana da vida harmoniosa em conjunto) mas não de vitimização (KROG, 1998, p. VII).

A vontade de realizar um intercâmbio de testemunhos e a possibilidade de apresentar narrativas que por vezes se contradizem impulsionam uma aproximação da verdade (compreendida, aqui, no sentido hermenêutico, de busca que jamais alcançará um fim). Mas, evidentemente, compartilhar histórias não irá produzir uma reconciliação instantânea, é necessário tempo para que a memória transforme a compulsão a repetição em uma fala que cura. Paciência, perseverança e comprometimento são necessários. Demandas por justiça e verdade podem reverberar por muitos anos no debate político independentemente dos sucessos e fracassos das comissões. Além disso, devemos estar atentos ao fato de que é difícil avançar (e por vezes possível retroceder) em situações em que a exposição da verdade é realizada de maneira desestruturada. A fala sobre o passado precisa estar ligada a fins específicos e ocorrer em um ambiente adequado. 0 desafio é trazer os conflitos para o discurso de modo que eles não se transformem em violência. Nesse aspecto, a Comissão sul-africana foi certamente bem sucedida e influenciou teorias de resolução de conflitos em diversos países.

Parece-nos que caso sul-africano é um exemplo concreto que pode nos ajudar a pensar a ligação sugerida por Ricoeur entre os campos da ética, do qual faz parte o perdão, e do direito, que abarca os diferentes tipos de anistia. Como vimos, o perdão extravasa o direito, mas pode ter efeitos secundários na ordem jurídica. Diferentemente do caso brasileiro, o tipo de anistia realizada na África do sul criou um ambiente de zelo pela memória, pela confissão e pelo pedido de perdão. Nesse sentido, os sul-africanos nos mostram que o direito não pode, de fato, garantir o perdão; pode, contudo, auxiliar na construção de condições favoráveis para a sua realização. 


\section{REFERÊNCIAS}

AFRICA DO SUL. Lei n. 34, de julho de 1995. Promotion of National Unity and Reconciliation Act. Disponível em: <http://www.justice.gov.za/legislation/acts/1995-034.pdf>. Acesso em: 8 set. 2017.

ÁFRICA DO SUL. Truth and Reconciliation Commission of South Africa Report, v 1, 1998. Disponível em: <http://www.justice.gov.za/trc/report/finalreport/Volume\%201.pdf>. Acesso em: 8 set. 2017.

BRASIL. Lei n. 6.683, de 28 de agosto de 1979. Lei de Anistia. Diário Oficial da União, Brasília, 28 out. $1979 . \quad$ Disponível em: <http://www.planalto.gov.br/ccivil_03/leis/L6683.htm>. Acesso em: 4 ago. 2017.

BRASIL. Supremo Tribunal Federal. Arguição de Descumprimento de Preceito Fundamental 153/DF, abril 2010. Min Relator: Eros Grau. Disponível em: http://www.stf.jus.br/arquivo/cms/noticianoticiastf/anexo/adpf153.pdf. Acesso em: 4 ago. 2017.

BUTLER, Judith. Precarious life: the powers of mourning and violence. London \& New York: Verso, 2004.

DIMOULIS, Dimitri. A Lei da Anistia entre presente e futuro. Site: Migalhas. Publicado em 4 de junho de 2010. Disponível em: <http://www.migalhas.com.br /dePeso/16, MI109059,21048-A+Lei+da+Anistia+entre+presente+e+futuro>. Acesso em: 4 ago. 2017.

DUFFY, Maria. Paul Ricoeur's pedagogy of pardon: a narrative theory of memory and forgetting. London \& New York: Continuum, 2009.

FREUD, Sigmund. Recordar, Repetir, Elaborar. In S. Freud, Obras completas v. 10. São Paulo, SP: Companhia das Letras, 2010b, p. 146-158. (Trabalho original publicado em 1914).

FREUD, Sigmund. Luto e Melancolia. In S. Freud, Obras completas v. 12. São Paulo, SP: Companhia das Letras, 2010b, p. 121-144. (Trabalho original publicado em 1915).

FREUD, Sigmund. Além do Princípio do Prazer. In S. Freud, Obras completas, v. 14. São Paulo, SP: Companhia das Letras, 2010c, p121-178 (Trabalho original publicado em 1920).

KEHL, Maria Rita. Melancolia e Criação. In: FREUD, Sigmund. Luto e melancolia. São Paulo: CosacNaify, 2012.

KROG, Antje. Country of My Skull. The Story of South Africa's Truth and Reconciliation Commission. Johannesburg: Random House, 1998.

PONS, Sophie. L'aveuet le pardon. Paris: Bayard. 2000.

RICOEUR, Paul. Da interpretação: ensaio sobre Freud. Rio de Janeiro: Imago, 1977.

RICOEUR, Paul. O perdão pode curar? Viragem, n. 21, 1996, pp. 26-2.

RICOEUR, Paul. A memória, a história, o esquecimento. Campinas-SP: EdUnicamp, 2007. 
RICOEUR, Paul. O Justo 1: a justiça como regra moral e como instituição. São Paulo: Martins Fontes, 2008.

RICOEUR, Paul. Escritos e conferências I. Em torno da psicanálise. São Paulo: Loyola, 2010. RICOEUR, Paul. Teoria da interpretação: o discurso e o excesso de significação. Lisboa: Edições 70, 2013

RICOEUR, Paul. O si-mesmo como outro. São Paulo: Martins Fontes, 2014

REIS, Daniel Aarão. Ditadura militar, esquerdas e sociedade. Rio de Janeiro: Zahar, 2000.

REIS, Daniel Aarão. Ditadura, anistia e reconciliação. Estudos de História, Rio de Janeiro, v. 23, n. 45, p. 171-186, Jun. 2010 . Disponível em: <http://www.scielo.br/scielo.php? script=sci_arttext\&pid=S0103$21862010000100008 \& \operatorname{lng}=e n \& n r m=i s o>$. Acesso em: 4 ago. 2017.

SAFATLE, Vladimir. Circuito dos afetos: corpos políticos, desamparo, fim do indivíduo. São Paulo: Cosac Naify, 2015.

TELES, Edson. Brasil e África do Sul: os paradoxos da democracia. Memória política em democracias com heranças autoritárias. Tese de Doutorado. Universidade de São Paulo, 2007. Disponível em: <http://www.teses.usp.br/teses/disponiveis/8/8133/tde-10102007150946/pt-br.php>. Acesso em: 8 set. 2017. 